\title{
PENGARUH SENAM DIABETES MELITUS (DM) TERHADAP PERUBAHAN TEKANAN DARAH PADA PASIEN DM TIPE 2 DI PERSADIA UNIT RSUD DR. MOEWARDI DI SURAKARTA TAHUN 2015
}

\author{
Amalia Nuril Afifah, Akhmad Rifa'i \\ Kementerian Kesehatan Politeknik Kesehatan Surakarta Jurusan Keperawatan
}

\begin{abstract}
Type 2 Diabetes Mellitus, Blood Pressure, Gymnastics Diabetes. Diabetes Mellitus is a chronic metabolic disease or disorder with multiple etiologies is characterized by high blood sugar levels. World Health Organitation (WHO) said Indonesia ranks the seventh in the world as a country with the number of people with diabetes mellitus. More than 50\% of patients with type 2 diabetes have hypertension (Sweetman, 2009). Management of diabetes disease that has been known there are three ways, namely arranging food, exercise, and medication. Exercise can cause the growth of new capillary blood vessels so as to reduce the blockage in the blood vessels which means it can lower blood pressure. The Objective of the research is to explain the influence of diabetes mellitus exercise to changes in blood pressure in patients with Type 2 diabetes mellitus in Persadia Hospital Dr. Moewardi Surakarta 2015. This type of research is quasy exsperiment to design one group pre and post test design, and data analysis used is frequency distribution univariate and bivariate test with paired samples t-test. Results of this study had a effect of diabetes mellitus exercise to changes in blood pressure in patients with Type 2 diabetes mellitus in Persadia Hospital Dr. Moewardi Surakarta. This is evidenced by paired sample t-test which obtained p value systole 0.01 and diastole 0.018 ( $p<0.05)$. The conclusion of the research there is the influence of diabetes mellitus exercise to changes in blood pressure in patients with Type 2 diabetes mellitus in Persadia Hospital Dr. Moewardi Surakarta.
\end{abstract}

Keywords: Type 2 Diabetes Mellitus, Blood Pressure, Gymnastics Diabetes

Abstrak : Diabetes Melitus Tipe II, Senam DM, Tekanan Darah. Diabetes Mellitus adalah suatu penyakit atau gangguan metabolisme kronis dengan multi etiologi yang ditandai dengan tingginya kadar gula darah. World Health Organitation (WHO) menyatakan Indonesia menempati urutan ke 7 di dunia sebagai negara dengan jumlah penderita diabetes mellitus. Lebih dari 50\% penderita DM tipe 2 mengalami hipertensi (Sweetman, 2009). Penatalaksanaan penyakit DM yang telah dikenal ada 3 cara, yaitu mengatur makanan, olahraga, dan obat-obatan. Olahraga yang teratur dapat digunakan sebagai program pengobatan DM, terutama diabetes tipe II dan sudah dikenal sejak lama selain diet dan obat-obatan. Menurut Kusmana (2008), olahraga dapat menurunkan tekanan darah. Olahraga dapat menyebabkan pertumbuhan pembuluh darah kapiler yang baru sehingga dapat mengurangi penyumbatan dalam pembuluh darah yang berarti dapat menurunkan tekanan darah. Tujuan Penelitian ini adalah untuk menjelaskan pengaruh senam diabetes mellitus terhadap perubahan tekanan darah pada pasien DM Tipe 2 di persadia RSUD Dr. Moewardi Surakarta tahun 2015. Jenis penelitian ini 
adalah quasy exsperiment dengan rancangan one group pre and post test design, dan analisis data yang digunakan adalah uji univariat dengan distribusi frekuensi dan uji bivariat dengan paired sampel t-test. Hasil penelitian ini adalah ada pengaruh senam diabetes mellitus terhadap perubahan tekanan darah pada pasien DM Tipe 2 di persadia RSUD Dr. Moewardi Surakarta. Hal ini dibuktikan dengan uji paired sampel t-test yang mana diperoleh nilai $\mathrm{p}$ value sistol 0,01 dan diastole $0,018(\mathrm{p}<0,05)$.

Kesimpulan dari penelitian ini adalah Ada pengaruh senam diabetes mellitus terhadap perubahan tekanan darah pada pasien DM Tipe 2 di persadia RSUD Dr. Moewardi Surakarta

Kata Kunci : Diabetes Melitus Tipe II, Senam DM, Tekanan Darah

\section{PENDAHULUAN}

Pembangunan kesehatan Indonesia diarahkan guna mencapai pemecahan masalah kesehatan untuk hidup sehat bagi setiap penduduk agar dapat mewujudkan derajat kesehatan yang optimal. Masalah kesehatan dapat dipengaruhi oleh pola hidup, pola makan, lingkungan kerja, olahraga dan stres. Perubahan gaya hidup terutama di kota-kota besar, menyebabkan meningkatnya prevalensi penyakit degeneratif, seperti diabetes melitus (DM) dan lain-lain (Waspadji, 2009).

Data Organisasi Kesehatan Dunia World Health Organitation (WHO) menyatakan Indonesia menempati urutan ke 7 di dunia sebagai Negara dengan jumlah penderita diabetes melitus terbanyak setelah India, China, Amerika Serikat, Uni Soviet, Jepang dan Brazil.. WHO memastikan peningkatan pada penderita Diabetes Melitus terutama tipe II paling banyak dialami oleh negara negara berkembang termasuk Indonesia (Suyono, 2007).

Laporan Riset Kesehatan Dasar (RISKESDAS) tahun 2013 menyebutkan terjadi peningkatan prevalensi pada penderita diabetes melitus yang diperoleh berdasarkan wawancara yaitu $1,1 \%$ pada tahun 2007 menjadi 1,5\% pada tahun 2013 sedangkan prevalensi diabetes melitus berdasarkan diagnosis dokter atau gejala pada tahun 2013 sebesar 2,1\% dengan prevalensi terdiagnosis dokter tertinggi pada daerah Sulawesi Tengah $(3,7 \%)$ dan paling rendah pada daerah Jawa Barat $(0,5 \%)$.

Anggota komunitas Persadia Unit RSUD Dr. Moewardi yang mengikuti kegiatan Persadia setiap minggunya berjumlah 50 orang, dengan 30 orang diantaranya pasien Penderita DM Tipe II. (Persadia Unit RSUD Dr. Moewardi Surakarta, 2014). Prevalensi populasi hipertensi pada diabetes adalah 1,5 -3 kali lebih tinggi daripada kelompok pada non diabetes. Diagnosis dan terapi hipertensi sangat penting untuk mencegah penyakit kardiovaskular pada individu dengan diabetes (Anonim, 2002). Pada diabetes tipe 2, hipertensi disajikan sebagai sindrom metabolit (yaitu obesitas, hiperglikemia, dyslipidemia) yang disertai oleh tingginya angka penyakit kardiovaskular (Anonim, 2006).

Berdasarkan data tersebut menunjukan bahwa kejadian penyakit DM belum mengalami penurunan, hal ini disebabkan beberapa factor. Adanya factor predisposisi terjadinya diabetes mellitus diantaranya usia, kurang olahraga, kebiasaan makan banyak kalori, riwayat diabetes dalam keluarga, riwayat 
diabetes gestasional terdahulu (Nabyl, 2009). Pengelolaan diabetes melitus meliputi 4 pilar dan aktivitas fisik merupakan salah satu dari empat pilar tersebut. Kegiatan fisik akan meningkatkan rasa nyaman baik secara fisik, psikis maupun sosial dan tampak sehat. Pada pasien DM tipe 2 sebagian besar penatalaksanaan penyakit diabetes menggunakan obat, padahal obat tidak merupakan satu-satunya cara yang dapat digunakan untuk penatalaksanaan penyakit DM. Prinsip olahraga senam diabetes Indonesia bagi penderita DM harus mengikuti petunjuk yang telah ditentukan, yaitu (1) Program latihan, (2) Porsi latihan, dan (3) Latihan kaki. Di samping mengikuti petunjuk tersebut, penderita masih mengikuti petunjuk lainnya demi keberhasilan dalam mengikuti latihan senam DM tersebut.

\section{METODE PENELITIAN}

Penelitian ini merupakan penelitian kuantitatif, penelitian ini dilakukan menggunakan pendekatan quasi exsperiment dengan one group pre and post test design yaitu untuk mengetahui pengaruh senam DM terhadap perubahan tekanan darah pada pasien DM tipe 2 di persadia RSUD Dr. Moewardi Surakarta. Rancangan penelitian quasi exsperiment dengan one group pre test and post test design adalah rancangan penelitian yang menggunakan satu kelompok subyek dengan cara melakukan pengukuran sebelum dan setelah perlakuan. Perbedaan kedua hasil pengukuran dianggap sebagai efek perlakuan. (Saryono, 2011).Jumlah sampel 30 responden sesuai dengan kriteria inklusi dan eksklusi.

Analisa univariat disajikan distribusi frekuensi karakteristik responden (Umur, Jenis kelamin tekanan darah sitol dan diastol sebelum dilakukan senam DM dan tekanan darah sistol dan diastol sesudah dilakukan senam DM).

Analisis Bivariat dilakukan untuk mengetahui bagaimana pengaruh senam DM terhadap perubahan teknana darah pasien DM Tipe II. Pada analisa bivariat ini peneliti akan melakukan uji normalitas data menggunakan Shapiro-wilk. Data berdistribusi normal menggunakan uji statistik parametric. Pengujian hipotesis parametrik yang digunakan adalah dengan uji paired sample t-test, karena dilihat dari skala data yang digunakan termasuk numerik dan sampel yang digunakan adalah sampel berpasangan.

\section{HASIL PENELITIAN}

Berdasarkan Karakteristik responden sebaran jenis kelamin responden dicermati pada tabel 1

\section{Tabel 1}

\section{Distribusi Frekuensi Responden} berdasarkan Jenis Kelamin pasien DM Tipe 2 di Persadia RSUD Dr. Moewardi Surakarta

\begin{tabular}{lcc}
\hline Jenis Kelamin & Jumlah $(\mathbf{n})$ & Persen $(\%)$ \\
\hline Laki-laki & 10 & 33.3 \\
Perempuan & 20 & 66.7 \\
\hline Total & 30 & 100 \\
\hline
\end{tabular}

Berdasarkan tabel 1 menunjukkan bahwa jenis kelamin pasien DM Tipe 2 yang ikut senam DM di Persadia Unit RSUD Dr. Moewardi sebagian besar adalah perempuan sejumlah 20 responden $(66.7 \%)$ dan sebagian kecil adalah lakilaki sejumlah 10 responden (33.3\%). 
Tabel 2

Distribusi Frekuensi Responden Berdasarkan Usia Dilakukan Senam DM Pada Pasien DM Tipe 2 di Persadia RSUD Dr. Moewardi Surakarta

\begin{tabular}{|c|c|c|}
\hline Usia & Jumlah (n) & Persen (\%) \\
\hline $\begin{array}{l}\text { Dewasa } \\
\text { akhir } 36-45 \\
\text { tahun }\end{array}$ & 1 & 3.3 \\
\hline $\begin{array}{l}\text { Lansia awal } \\
46-55 \text { tahun }\end{array}$ & 10 & 33.3 \\
\hline $\begin{array}{l}\text { Lansia } \\
\text { akhir 56-65 } \\
\text { tahun }\end{array}$ & 13 & 43.3 \\
\hline $\begin{array}{l}\text { Manula }>65 \\
\text { tahun }\end{array}$ & 6 & 20.0 \\
\hline Total & 30 & 100 \\
\hline
\end{tabular}

keseluruhan responden yang dilakukan senam Diabetes Mellitus (DM) adalah sebanyak 30 responden. Dari jumlah responden tersebut yang paling banyak pada responden usia 56-65 tahun sebanyak 13 responden

Tabel 3

Distribusi Frekuensi Tekanan Darah Sistol Responden Sebelum Dilakukan Senam DM Pada Pasien DM Tipe 2 di Persadia RSUD Dr. Moewardi Surakarta

\begin{tabular}{|c|c|c|}
\hline $\begin{array}{c}\text { Variable } \\
\text { (tekanan darah ) }\end{array}$ & $\underset{\text { (n) }}{\text { Jumlah }}$ & $\begin{array}{c}\text { Persen } \\
(\%)\end{array}$ \\
\hline $\begin{array}{l}\text { normal-tinggi (130- } \\
139)\end{array}$ & 6 & 20.0 \\
\hline $\begin{array}{l}\text { hipertensi derajat } 1 \\
(140-159)\end{array}$ & 17 & 56.7 \\
\hline $\begin{array}{l}\text { hipertensi derajai } 2 \\
(160-179)\end{array}$ & 6 & 20.0 \\
\hline $\begin{array}{l}\text { hipertensi derajat } 3 \\
(>180)\end{array}$ & 1 & 3.3 \\
\hline Total & 30 & 100.0 \\
\hline
\end{tabular}

keseluruhan responden yang dilakukan senam Diabetes Mellitus (DM) adalah sebanyak 30 responden. Dari jumlah responden tersebut tekanan darah sistol responden sebelum senam paling banyak mengalami hipertensi derajat 1 dengan jumlah 17 responden $(56,7 \%)$.

\section{Tabel 4}

Distribusi Frekuensi Tekanan Darah Diastol Responden Sebelum Dilakukan Senam DM pada pasien DM Tipe 2 di Persadia RSUD Dr. Moewardi Surakarta.

\begin{tabular}{|c|c|c|}
\hline $\begin{array}{c}\text { Variable (tekanan } \\
\text { darah ) }\end{array}$ & $\begin{array}{c}\text { Jumlah } \\
\text { (n) }\end{array}$ & $\begin{array}{c}\text { Persen } \\
(\%)\end{array}$ \\
\hline optimal $(<80)$ & 11 & 36.7 \\
\hline normal-tinggi $(85-89)$ & 7 & 23.3 \\
\hline $\begin{array}{l}\text { hipertensi derajat } 1 \\
\text { (90-99) }\end{array}$ & 9 & 30.0 \\
\hline $\begin{array}{l}\text { hipertensi derajat } 2(100- \\
109)\end{array}$ & 3 & 10.0 \\
\hline Total & 30 & 100.0 \\
\hline
\end{tabular}
keseluruhan responden yang dilakukan senam Diabetes Mellitus (DM) adalah sebanyak 30 responden. Dari jumlah responden tersebut tekanan darah diastol responden sebelum senam paling banyak tekanan darahnya optimal yaitu dengan jumlah 11 responden $(36,7 \%)$.

\section{Tabel 5}

Distribusi Frekuensi Tekanan Darah Sistol Sesudah Dilakukan Senam Pada Pasien DM Tipe 2 di Persadia RSUD Dr. Moewardi Surakarta.

\begin{tabular}{|c|c|c|}
\hline $\begin{array}{c}\text { Variabel (tekanan } \\
\text { darah ) }\end{array}$ & Jumlah (n) & $\begin{array}{c}\text { Persen } \\
(\%)\end{array}$ \\
\hline optimal $(<120)$ & 5 & 16.7 \\
\hline normal <130 & 6 & 20.0 \\
\hline $\begin{array}{l}\text { normal-tinggi (130- } \\
\text { 139) }\end{array}$ & 8 & 26.7 \\
\hline $\begin{array}{l}\text { hipertensi derajat } \\
1(140-159)\end{array}$ & 11 & 36.7 \\
\hline Total & 30 & 100.0 \\
\hline
\end{tabular}
keseluruhan responden yang dilakukan senam Diabetes Mellitus (DM) adalah sebanyak 30 responden. Dari jumlah 
responden tersebut tekanan darah sistol responden setelah senam paling banyak mengalami hipertensi derajat 1 dengan jumlah 11 responden $(36,7 \%)$.

\section{Tabel 6}

Distribusi Frekuensi Tekanan Darah Diastol Sesudah Dilakukan Senam pada pasien DM Tipe 2 di persadia RSUD

\section{Dr. Moewardi Surakarta.}

\begin{tabular}{|c|c|c|}
\hline $\begin{array}{c}\text { Variabel } \\
\text { (tekanan darah ) }\end{array}$ & $\begin{array}{l}\text { Jumlah } \\
\text { (n) }\end{array}$ & Persen (\%) \\
\hline optimal $(<80)$ & 9 & 30.0 \\
\hline Normal $(<85)$ & 8 & 26.7 \\
\hline $\begin{array}{l}\text { normal-tinggi } \\
(130-139)\end{array}$ & 7 & 23.3 \\
\hline $\begin{array}{l}\text { hipertensi derajat } \\
1 \\
(140-159)\end{array}$ & 6 & 20.0 \\
\hline Total & 30 & 100.0 \\
\hline
\end{tabular}

keseluruhan responden yang dilakukan senam Diabetes Mellitus (DM) adalah sebanyak 30 responden. Dari jumlah responden tersebut tekanan darah diastol responden setelah senam paling banyak mengalami tekanan darah optimal dengan jumlah 9 responden $(30,0 \%)$.

Berikut ini hasil analisis paired sample t-test terhadap perubahan tekanan darah sebelum dan sesudah dilakukan senam DM pada pasien DM Tipe 2 di persadia RSUD Dr. Moewardi Surakarta, disajikan pada tabel 7.

\section{Tabel 7}

Hasil Analisis Paired Sample T-Test Tekanan Darah Sebelum dan Sesudah Dilakukan Senam DM pada pasien DM Tipe 2 di persadia RSUD Dr. Moewardi Surakarta.

\begin{tabular}{|c|c|c|c|c|}
\hline Variabel & $\mathrm{n}$ & Mean & $\begin{array}{l}\text { Std. } \\
\text { Deviasi }\end{array}$ & $\begin{array}{l}\mathrm{P} \text { va- } \\
\text { lue }\end{array}$ \\
\hline $\begin{array}{lr}\text { Tekanan } & \text { darah } \\
\text { sistol } & \text { sebelum } \\
\text { dilakukan } & \text { senam } \\
\text { DM. } & \end{array}$ & 30 & 145,83 & 11,378 & \\
\hline $\begin{array}{lr}\text { Tekanan } & \text { darah } \\
\text { sistol } & \text { sesudah } \\
\text { dilakukan } & \text { senam } \\
\text { DM. } & \end{array}$ & 30 & 129,67 & 14,016 & .000 \\
\hline $\begin{array}{lr}\text { Tekanan } & \text { darah } \\
\text { diastol Sebelum } \\
\text { dilakukan senam } \\
\text { DM. }\end{array}$ & 30 & 85,17 & 8,758 & \\
\hline $\begin{array}{lr}\text { Tekanan } & \text { darah } \\
\text { diastol } & \text { sesudah } \\
\text { dilakukan } & \text { senam } \\
\text { DM. } & \end{array}$ & 30 & 81,33 & 6,687 & .018 \\
\hline
\end{tabular}

Hasil uji paired t-test pengaruh senam Diabetes Mellitus (DM) terhadap perubahan tekanan darah menunjukkan hasil nilai $\mathrm{p}$ value untuk tekanan darah sistol yaitu 0,001 atau $<0,05$, dan untuk tekanan darah diastol yaitu 0,018 atau < 0,05 dengan perubahan rata-rata sistol sebelum dan sesudah rata-rata 145,83 menjadi 129,67. Perubahan rata-rata diastole sebelum dan sesudah rata-rata 8,758 menjadi 6,687. Dari hasil uji paired t-test dapat diartikan bahwa Ho ditolak dan $\mathrm{Ha}$ diterima yang artinya ada pengaruh senam Diabetes Mellitus (DM) terhadap tekanan darah. 


\section{PEMBAHASAN}

Hasil analisis menunjukkan jumlah responden perempuan sejumlah 20 responden $(66.7 \%)$ dan responden lakilaki sejumlah 10 responden (33.3\%). Jumlah responden perempuan dapat dilihat jumlahnya lebih banyak dibandingkan responden laki-laki. Hasil penelitian ini juga sesuai dengan teori yang dikemukakan Mansjoer, 2000 dan Therney, 2002 yang menyebutkan pasien perempuan lebih banyak daripada pasien laki-laki. Hal ini dikarenakan sebagian faktor yang dapat mempertinggi resiko DM tipe 2 yang dialami oleh perempuan, seperti riwayat kehamilan dengan berat badan lahir bayi > $4 \mathrm{~kg}$, riwayat $\mathrm{DM}$ selama kehamilan (diabetes gestasional), obesitas, penggunaan kontrasepsi oral, dan tingkat stress yang cukup tinggi (Mansjoer, 2000; Therney, 2002).

Hasil penelitian menunjukkan bahwa responden yang mengalami diabetes tipe 2 lebih banyak pada usia 56 65 tahun yaitu sebanyak 13 lansia (43,3\%). Menurut Smeltzer \& Bare,(2002) umumnya penderita DM tipe II mengalami perubahan fisiologi yang secara drastis, DM tipe II sering muncul setelah usia 30 tahun ke atas dan pada mereka yang berat badannya berlebihan sehingga tubuhnya tidak peka terhadap insulin. Menurut anonym, (2002) prevalensi populasi hipertensi pada diabetes adalah 1,5-3 kali lebih tinggi daripada kelompok pada non diabetes. Harrison, Wilson dan Kasper (2005) menyatakan bahwa semakin tinggi usia seseorang maka semakin tinggi tekanan darahnya. Hal ini didukung oleh hasil penelitian Saputri (2009), yaitu sebagian besar responden yang berusia 50 tahun ke atas sebanyak 70 responden dan yang memiliki tekanan darah paling tinggi yaitu responden berusia 60 tahun ke atas sebanyak 52 responden. Ini disebabkan karena semakin bertambahnya usia arteri kehilangan elastisitas atau kelenturan, sehingga volume darah yang mengalir sedikit dan kurang lancar. Semakin bertambahnya usia seseorang, pengaturan metabolisme zat kapur (kalsium) terganggu, sehingga banyak zatkapur yang beredar bersama darah. Banyaknya kalsium dalam darah (hypercalcedemia), menyebabkan darah menjadi lebih padat, sehingga tekanan darah menjadi meningkat. Endapan kalsium di dinding pembuluh darah menyebabkan penyempitan pembuluh darah, akibatnya aliran darah menjadi terganggu. Hal ini dapat memacu peningkatan tekanan darah (Timio dan Verdecchia, 2005).

Sebelum dilakukan senam DM, peneliti melakukan penilaian tekanan darah menggunakan spignomanometer. Klasifikasi tekanan darah yang dipilih adalah Menurut Seventh Report of the Joint National Committe VII (JNC VII) on Prevention, Detection, Evaluationand Treatment of High Blood Pressure. Paling banyak mengalami hipertensi derajat 1 dengan jumlah 17 responden $(56,7 \%)$. Hipertensi yang dialami responden terjadi karena dipengaruhi oleh berbagai macam faktor resiko baik yang bisa dikontrol seperti aktivitas olahraga, merokok, alkohol, mengkonsumsi garam dapur, obesitas dan stress serta faktor resiko yang tidak dapat dikontrol seperti usia, jenis kelamin dan keturunan (genetik) (Harrison, Wilson dan Kasper, 2005).

Menurut hasil observasi penelitian, paling banyak faktor pemicu responden terkena hipertensi yaitu kurangnya aktivitas olahraga serta dari faktor resiko yang tidak dapat dikontrol karena bertambahnya usia mereka. Kurangnya 
latihan aktivitas fisik pada penderita DM bisa mengakibatkan hipertensi dikarenakan terjadinya penurunan cardiac output (curah jantung) sehingga pemompaan ke jantung menjadi lebih berkurang. Kurangnya latihan aktivitas fisik juga dapat menyebabkan terjadinya kekakuan pembuluh darah, sehingga aliran darah tersumbat dan dapat menyebabkan hipertensi (Giriwijoyo, 2007). Tekanan Darah Sesudah Dilakukan Senam DM

Pemberian senam DM kepada responden yang mengalami diabetes tipe 2 dilakukan 45 menit sebanyak 1 kali dalam 1Minggu sesuai dengan penjadwalan yang ada di persadia RSUD Dr. Moewardi Surakarta. Dari 50 penderita diabetes. Peneliti memilih responden yang memenuhi kriteria inklusi, dipilih 30 responden yang dijadikan sampel. Distribusi frekuensi responden menunjukkan tekanan darah setelah diberikan intervensi tekanan. Responden yang mengalami penurunan tekanan darah yang dikarenakan mereka aktif mengikuti gerakan senam dan mengikuti prosedur senam DM yang benar secara berkontinuitas yaitu melakukan latihan pemanasan, latihan inti serta latihan pendinginan atau latihan penutup. Untuk responden yang tekanan darahnya tetap dan tekanan darahnya mengalami kenaikan karena responden memiliki berat badan yang agak berlebih, gerakan senamnya tidak secara berkontinuitas serta ada beberapa responden yang memang memiliki garis keturunan atau keadaan genetiknya memang hipertensi.

Perubahan Tekanan Darah Sebelum Dan Sesudah Dilakukan Senam DM. Dari penelitian yang telah dilakukan di persadia unit RSUD Dr.Moewardi Surakarta pada belan Februari didapatkan hasil bahwa terdapat pengaruh senam DM terhadap perubahan tekanan darah yang artinya Ha diterima atau Ho ditolak. Berdasarkan uji paired t-test pengaruh senam DM terhadap tekanan darah menunjukkan hasil mean sistol sebelum senam 145,83 dengan standar deviasi 11,378 . Untuk mean sistol sesudah senam 129,67 dengan standar deviasi 14,016 sedangkan untuk mean diastole sebelum senam 85,17 dengan standar deviasi 8,758 dan mean diastole sesudah senam 81,33 dengan standar deviasi 6,687. Dapat dijelaskan bahwa standar deviasi, semakin besar penyimpangan data dari rata-rata hitungnya, sehingga dikatakan data memilik variabilitas tinggi. Artinya, data di antara anggota elemen adalah heterogen. Sebaliknya, semakin rendah deviasi standar, semakin rendah penyimpangan data dari rata-rata hitungnya, sehingga dikatakan data memiliki variabilitas rendah. Artinya, data di antara anggota elemen adalah homogeny. Nilai $\mathrm{p}$ value untuk tekanan darah sistolik yaitu 0,001 atau $<0,05$, dan untuk tekanan darah diastolik yaitu 0,018 dengan perubahan rata-rata sistole sebelum dengan sesudah yaitu sebesar $16,167 \mathrm{mmHg}$ dan perubahan rata-rata diastole $3,833 \mathrm{mmHg}$.

Hasil penelitian tersebut sejalan dengan penelitian yang dilakukan oleh Margiyati (2010), yaitu setelah senam lansia hasil penelitian menunjukkan 91,67\% responden mengalami penurunan rata-rata tekanan darah sistolik 10,69 $\mathrm{mmHg}$ dan diastolik 6,11 $\mathrm{mmHg}$. Sebanyak $50 \%$ responden dengan hipertensi derajat 1 turun menjadi 41,67\% sesudah perlakuan. Berdasarkan uji Paired Sampel T-test diperoleh hasil 0.000 untuk nilai sistolik dan 0.001 untuk nilai diastolik, keduanya lebih kecil dari $\mathrm{p}$ 
value 0.05 sehingga disimpulkan terdapat pengaruh pelaksanaan senam lansia terhadap penurunan tekanan darah pada lansia penderita hipertensi. Hal ini diperkuat dengan teori yang menyatakan bahwa. Melakukan olahraga yang teratur dapat menurunkan tekanan darah dikarenakan latihan jasmani yang teratur dapat melebarkan pembuluh darah (Kusmana, 2006).

Menurut Harber, (2009) Latihan aktivitas fisik akan memberikan pengaruh yang baik terhadap berbagai macam sistem yang bekerja di dalam tubuh, salah satunya adalah sistem kardiovaskuler. Saat melakukan aktivitas fisik, tekanan darah akan naik cukup banyak. Tekanan darah sistolik yang misalnya semula 110 mmHg sewaktu istirahat akan naik menjadi $150 \mathrm{mmHg}$. Sebaliknya, segera setelah latihan fisik selesai, tekanan darah akan turun sampai di bawah normal dan berlangsung 30-120 menit. Kalau olahraga dilakukan berulang-ulang, lama-kelamaan penurunan tekanan darah akan berlangsung lama. Itulah sebabnya latihan aktivitas fisik senam yang dilakukan secara teratur bisa menurunkan tekanan darah.. Frekuensi latihannya 3-5 kali seminggu dengan lama latihan 20-60 menit sekali latihan. Penurunan tekanan darah ini antara lain terjadi karena pembuluh darah mengalami pelebaran dan relaksasi. Lama kelamaan, latihan olahraga dapat melemaskan pembuluhpembuluh darah, sehingga tekanan darah menurun. Rutin berolahraga sangat kuat, maka otot jantung dari individu yang rajin berolahraga berkontraksi lebih sedikit daripada otot jantung orang yang jarang berolahraga untuk memompakan volume darah yang sama. Karena latihan aktivitas fisik senam dapat menyebabkan penurunan denyut jantung maka akan menurunkan cardiac output, yang pada akhirnya menyebabkan penurunan tekanan darah. Dari uraian diatas peneliti dapat menyimpulkan bahwa ada pengaruh senam DM terhadap perubahan tekanan darah, dimana senam DM dapat menurunkan tekanan darah baik sistole maupun diastole. Hal ini terjadi Penurunan tekanan darah karena pembuluh darah mengalami pelebaran dan relaksasi. Lama kelamaan, latihan olahraga dapat melemaskan pembuluhpembuluh darah, sehingga tekanan darah menurun.

\section{KESIMPULAN DAN SARAN}

Berdasarkan hasil penelitian yang telah dilakukan terhadap 30 responden yang mengalami DM Tipe 2 di persadia unit RSUD Dr. Moewardi Surakarta dapat disimpulkan bahwa Tekanan darah sistol sebelum dilakukan senam Diabetes Mellitus (DM) pada pasien DM Tipe 2 di persadia RSUD Dr. Moewardi Surakarta rata- rata hipertensi derajat 1 dengan jumlah 17 responden, dan tekanan darah diastol rata-rata optimal dengan jumlah 11 responden.

Tekanan darah sistol sesudah dilakukan senam Diabetes Mellitus (DM) pada pasien DM Tipe 2 di persadia RSUD Dr. Moewardi Surakarta rata-, rata hipertensi derajat 1 dengan jumlah 11 responden, dan tekanan darah diastol ratarata optimal 9 responden.

Senam diabetes mellitus (DM) berpengaruh terhadap perubahan tekanan darah pada pasien DM Tipe 2 di persadia RSUD Dr. Moewardi Surakarta. Saran Berdasarkan hasil penelitian yang telah dilakukan, penulis memberikan saran sebagai berikut : Bisa mendorong masyarakat yang menderita diabetes mellitus (DM) maupun yang mempunyai 
riwayat diabetes untuk mengikuti senam DM agar tercapainya kualitas hidup yang optimal dengan terkendalinya gula darah maupun tekanan darah.

\section{DAFTAR RUJUKAN}

American Diabetes Association (ADA). (2005). Diagnosis and Classification of Diabetes Mellitus. Tersedia di http://care.diabetesjournals.org Diunduh 23 januari 2014.

Anonim. (2002). Faktor Pemicu Timbulnya Diabetes Mellitus. Tersedia Di http://www.chungjaya-abadi. Diunduh 12 Februari 2015.

Direktorat Bina Farmasi Komunitas dan Klinik. (2009). Pharmaceutical Care Untuk Penyakit Diabetes Mellitus. Direktorat Jenderal Bina Kefarmasian Dan Alat Kesehatan : Departemen Kesehatan RI.

Giriwijoyo, S. (2007). Olahraga Untuk Kesehatan. Jakarta : Balai Pustaka. Hardiwinoto. (2009). Kategori Umur. Depkes : Jakarta.

Harrison, I., \& Wilson, B.W., (2005). Prinsip-Prinsip Ilmu Penyakit Dalam. Edisi 13 Volume 3. Jakarta : EGC.

Mansjoer, A. (2001). Kapita Selekta Kedokteran Edisi Ketiga. Jakarta: Media Aesculapius.

Mafa'ul. (2014). Pengaruh Senam Kaki Diabetes Mellitus Terhadap Perubahan Tekanan Darah Pada Pasien DM Tipe 2 Non Ulkus Di Poliklinik Endokrin RSUP. Dr.
Wahidin Sudirohusodo Makassar.

Tersedia di http://repository.unhas.ac.id. Diunduh 1 Januari 2015.

Margiyati. (2010). Pengaruh Senam Lansia Terhadap Penurunan Tekanan Darah Pada Lansia Penderita Hipertensi di Posyandu Lansia Ngudi Waras Dusun Kemlok, Desa Bergas Kidul. Skripsi. Program sarjana UNDIP : Semarang.

Medical Record (2014) Persadia Unit RSUD dr. Moewardi Surakarta.

Nabyl. (2009). Mengenal Diabetes. Jakarta : Gramedia Pustaka Utama.

Palmer, A., dan Williams. (2007). Tekanan Darah Tinggi. Jakarta : Erlangga.

Saputri, D. (2009). Pengaruh Olahraga Senam Jantung Sehat Terhadap Tekanan Darah Pada Lanjut Usia Hipertensi di Klub Senam Jantung Sehat Mertoyudan Magelang. Surakarta: UMS.

Saryono. (2011). Metodologi penelitian keperawatan. Purwokerto: UPT Universitas Jenderal Soedirman.

Smeltzer, S.C \& Bare, B.G. (2002). Buku Ajar Medikal Bedah. Jakarta : EGC.

Timio, M \& Verdecchia, P. (2005). Blood Pressure Changes over 20 years in nuns in secluded order. journal Hypertention in Elderly.

Waspadji, S. (2009). Buku Ajar Ilmu Penyakit Dalam : Komplikasi Kronik Diabetes. Jakarta : Pusat Penerbit IPD FKUI. 